\title{
Transformasi Musik Balaganjur Teruna Goak ke dalam Musik Jazz
}

\author{
Ade Surya Firdaus, Hendra Santosa, Ni Wayan Ardini \\ Institut Seni Indonesia Denpasar \\ Jalan Nusa Indah, Sumerta, Denpasar, Kota Denpasar, Bali 80235 \\ Email: hendrasnts@gmail.com
}

\begin{abstract}
The Megoak-goakan tradition from a Panji Village that is played with Balaganjur Teruna Goak music is very interesting when it is transformed into jazz because it has the same basic musical form. This article aims to provide an overview of the process of transformation of Balaganjur Teruna Goak Village in Panji Village into jazz music. The process of transformation into jazz music was carried out with the creation method of exploratory which began with a literature study on the Megoak-goakan tradition in Panji Village, Buleleng, and then conducted participant observations, interviews, and continued with experiments on various musical motifs which were considered suitable with a jazz music. The results are obtained from observing and analyzing the process using the theory of basic form of music of Pono Banoe and Prier's. It is found that Balaganjur Teruna Goak's music had a lively expression with the phrases of antisedent (question) and consequent (answer). Furthermore, the experimental stage begins with pouring musical inspiration that is used in this work in several stages through writing notation. The formation step is done by assembling existing motifs and then formed into a unified whole composition. The creation of jazz music is based on Balaganjur music, and in its creating processes does not neglect the work of others so that it is possible that in its motifs and patterns on musical arrangements have adopted the previous works.
\end{abstract}

Keywords: Teruna Goak, Balaganjur, Jazz Music, Transformation, Panji Village

\section{ABSTRAK}

Tradisi Megoak-goakan dari Desa Panji dimainkan dengan musik Balaganjur Teruna Goak. Keduanya sangatlah menarik jika ditransformasikan ke dalam musik jazz karena memiliki bentuk dasar musik yang sama. Artikel ini bertujuan memberikan gambaran bagaimana proses transformasi musik Balaganjur Teruna Goak Desa Panji ke dalam musik jazz. Proses transformasi ke dalam musik jazz dilakukan dengan metode penciptaan dari penjajakan yang diawali dari studi literatur tentang tradisi Megoak-goakan di Desa Panji Buleleng, kemudian melakukan pengamatan langsung, wawancara, dan dilanjutkan dengan percobaan berba-gai motif musik yang diperkirakan cocok dengan musik jazz. Hasil yang didapat dari peng-amatan dan proses analisis menggunakan teori bentuk dasar musik Pono Banoe dan teori bentuk musik dari Prier. Musik Balaganjur Teruna Goak memiliki ekspresi yang bersemangat dengan frase antiseden (tanya) dan konsekuen (jawab). Selanjutnya, pada tahap percobaan dimulai dengan cara menuangkan inspirasi musik yang akan digunakan dalam garapan ini secara bertahap melalui penulisan notasi. Tahap pembentukan dilakukan dengan merangkai motif-motif yang telah ada kemudian dibentuk menjadi suatu kesatuan komposisi yang utuh. Penciptaan musik jazz yang berdasarkan musik Balaganjur ini, pada penggarapannya tidak mengabaikan hasil karya orang lain sehingga kemungkinan dari segi motif dan pola garap musikal mengadopsi yang sudah ada sebelumnya.

Kata kunci: Teruna Goak, Balaganjur, Musik Jazz, Transformasi, Desa Panji 


\section{PENDAHULUAN}

Permainan Megoak-goakan adalah permainan tradisional Bali dari Desa Panji, Kecamatan Sukasada Kabupaten Buleleng. Permainan ini adalah salah satu tradisi masyarakat Panji yang masih dipertahankan dan dimainkan pada saat ngembak geni, yang merupakan rangkaian Hari Raya Nyepi. Permainan ini dimainkan oleh anak-anak dan orang dewasa. Megoakgoakan ini diyakini oleh masyarakat setempat bertujuan untuk menjaga hubungan yang harmonis antar sesama masyarakat yang melakukan tradisi tersebut. Bentuk permainan tersebut adalah permainan yang dimainkan oleh 10 orang yang terdiri dari pemain putra dan putri yang diatur dalam barisan yang berselang-seling dan saling memegang ikat pinggang pemain lainnya. Pemain yang berada paling depan berperan sebagai burung gagak dan yang lainnya sebagai anak ayam, pemeran burung gagak berperan menangkap ayam yang berada di belakangnya.

Tradisi Megoak-goakan Desa Panji ini sangatlah menarik dan unik jika ditransformasikan ke dalam musik jazz. Dipilihnya musik jazz selain karena musik jazz adalah musik yang pencipta tekuni, juga lebih dapat mewakili setiap imajinasi yang ingin pencipta realisasikan ke dalam suatu nada. Jazz adalah musik yang syarat dengan improvisasi. Improvisasi adalah seni mengomposisi saat bermain, tanpa notasi tertulis yang telah lama dianggap sebagai suatu ciri khas yang membedakan jazz dan musik lainnya. Walaupun banyak kultur musikal dunia juga berimprovisasi dalam derajat tertentu.

Ada anggapan bahwa dalam musik tidak ada yang menitikberatkan kreativitas instan dalam permainannya, tempat musisi diharapkan mencapai taraf kreativitas tertentu, tapi musisi jazz berbicara dan berlaku seolah jazzlah satu-satunya jenis musik yang demikian. Mereka berbicara tentang melampaui batasan apa yang telah dikomposisikan, melampaui intepretasi ala kadarnya, dan menuju tingkat kreativitas yang lebih inspiratif dan lebih spontan. Suatu taraf yang memungkinkan orang yang berimprovisasi bersentuhan dengan kesadaran dan ketidaksadarannya (Szwed, 2000: 34).

Di dalam proses penggarapan karya Megoak-goakan Desa Panji dalam musik Jazz ini, pencipta mengawali proses tersebut dengan metode penciptaan dari Alma M. Hawkin (1990), yaitu dengan tiga tahapan yaitu eksplorasi, improvisasi, dan forming. Penjajakan dilakukan dengan mengumpulkan data melalui studi literatur, wawancara, dan dokumentasi serta melakukan pengamatan langsung terhadap obyek Megoak-goakan itu sendiri. Selanjutnya, pengolahan data dan melangkah ke tahap improvisasi dan perwujudan. Pada tahap eksplorasi sejarah ini, pencipta melihat hal yang menarik, yakni apabila musik iringan Megoak-goakan, yaitu musik Balaganjur Teruna Goak sangat unik jika ditransformasikan ke dalam musik jazz, karena memiliki bentuk dasar musik, seperti melodi, irama, tempo, harmoni, serta ekspresi dan dinamika yang mirip jika dimainkan dalam irama jazz. Balaganjur merupakan salah satu barungan gamelan yang ada di Bali. Istilah Balaganjur berasal dari kata Bala dan Ganjur. Bala Berarti pasukan atau barisan. Ganjur berarti berjalan (Antara, Sudirga, dan Santosa, 2018: 98). Di Bali sendiri, musik perang telah banyak mengalami perubahan menyesuaikan dengan waktu dan fungsinya (Santosa, 2018: 16-25).

Balaganjur adalah jenis musik prosesi yang telah mengalami perubahan dan kelanjutan yang sangat panjang dimulai dari Banjuran dan diakhiri oleh Adi Merdangga (Santosa, 2018: 144). Balaganjur sebagai musik tradisional Bali mempunyai elemen yang penting. Setidaknya, “ada dua elemen penting dalam musik tradisional Bali, yaitu ben- 
tuk dan konsep estetik. Bentuk dan konsep estetik akan memberikan identitas sebuah aktualitas musik sehingga dapat dibedakan dari yang lainnya" (Sugiartha, 2015a: 46). Dalam hal ini, konsep estetik musik tradisional Bali bersifat ilmiawi dan filsafati. Ilmiawi dapat dicermati dari analisa bentuk, struktur, dan proses perwujudan karya seni itu sendiri yang bersifat objektif. Sedangkan konsep estetika filsafati musik tradisional Bali berupa nilai tradisi dan kebiasaan yang telah menjadi bagian penting dan disepakati oleh masyarakat kendatipun sering bersifat irasional (Sugiartha, 2015a: 54).

Penggarapan karya ini juga tidak mengabaikan hasil karya orang lain sehingga memungkinkan adanya motif yang mengadopsi serta mengembangkan pola garap musikal yang sudah ada sebelumnya. Penggarapan musik ini juga terinspirasi dari latar belakang sejarah dari tradisi Megoakgoakan tersebut yang secara garis besar tidak terlepas dari kisah Raja Panji Sakti yang merebut kekuasan Kerajaan Blambangan.

Sejarah permainan Megoak-goakan ini berawal dari sejarah Ki Barak Panji Sakti dan Pasukannya dalam menggempur kerajaan Blambangan. Dikisahkan, Kerajaan Blambangan pada saat itu berada di bawah kekuasaan Mataram. Kerajaan Mataram di bawah pimpinan Amangkurat I dan kemudian Amangkurat II, yang pada saat itu memberi dukungan terhadap VOC, menyebabkan timbulnya pemberontakan-pemberontakan dari beberapa kalangan yang akhirnya membentuk aliansi anti VOC. Tidak hanya itu, beberapa pemberontak VOC tersebut banyak yang mencari perlindungan di bawah kerajaan Panji Sakti yang anti VOC dan selalu mendukung dan memberi bantuan kepada pemberontak (Sunan Mas, Trunojoyo, Untung Surapati) dalam menyediakan tempat untuk konsolidasi Trunojoyo (Sastrodiwiryo 2011:173). Raja Panji Sakti memerintahkan Ki Tamblang Sampun sebagai pemimpin militer untuk mengum- pulkan seluruh pasukan Teruna Goaknya di Puri Panji. Diawali dengan Upacara dan dilanjutkan dengan tari "Baris Goak" yang ditarikan sekitar 20 pasukan Teruna Goak. Sebagai awal mula, Raja Panji Sakti menyemangati dan mengajak serta memotivasi prajuritnya untuk menyerang kerajaan Blambangan. Inilah awal mula semangat pasukan Teruna Goak yang muncul seketika di saat Raja Panji Sakti mengutarakan keinginannya untuk menaklukkan Kerajaan Balambangan.

I Gusti Anglurah Panji menyadari bahwa prajurit Blambangan adalah pasukan yang berpengalaman dan terkenal kebal senjata dengan ilmu tenungnya. Maka, Laskar Den Bukit Teruna Goak harus mempersiapkan diri dengan segala kemampuan dan senjata yang dimiliki untuk melakukan persiapan yang matang. Teruna Goak terdiri dari empat kesatuan yang terbagi menjadi armada laut, pasukan panah, sumpit dan tombak, pasukan bedil atau senjata api, dan pasukan yang menangani urusan logistik. Setelah menentukan hari yang baik untuk melakukan penyerangan, pasukan Teruna Goak bertolak ke Blambangan di bawah pimpinan I Gusti Anglurah Panji.

Pertempuran antara Laskar Goak dan pasukan macan Putih Blambangan terjadi secara membabi buta menyebabkan banyak korban berjatuhan, mayat bergelimpangan, dan darah membasahi medan pertempuran. Keahlian pasukan Teruna Goak menggunakan senjata sumpit mengakibatkan banyak jatuh korban dari pihak pasukan Macan Putih Blambangan yang tidak mampu menandingi pasukan Laskar Goak. Setelah banyak jatuh korban, pasukan Blambangan ditarik mundur dan diperintahkan untuk mengamankan Istana Blambangan dan melindungi keluarga kerajaan. Namun, pada kenyataannya, Adipati Blambangan, Pangeran mas Sedah dan Pangeran Mas Pahit telah meninggalkan istana untuk melarikan diri ke Mataram. 
Di depan Istana Blambangan pasukan Teruna Goak mendapatkan perlawanan yang tidak berarti, I Gusti Anglurah Panji masuk untuk memeriksa keadaan istana namun I Gusti Anglurah Panji mendapati bahwa istana telah dalam keadaan kosong. I Gusti Anglurah Panji duduk di singgasana dalam balairung, yang disebut dengan Kertagosha. Kerajaan Blambangan dengan demikian dapat dikuasai oleh I Gusti Anglurah Panji dan pasukannya. Prajurit Blambangan yang berjumlah ribuan mulai menyerahkan diri kepada Patih I Gusti Tamblang dan mengucapkan sumpah setia kepada I Gusti Anglurah Panji Raja Den Bukit. Setelah menguasai Kerajaan Blambangan beberapa waktu, I Gusti Anglurah Panji menyerahkan kekuasaannya dan mengangkat putra tertuanya I Gusti Ngurah Wayan sebagai Raja Blambangan dengan pasukan prajurit berjumlah 600 orang (Sentanu, 2004). Demikian, cerita singkat mengenai sejarah tradisi ini.

Selanjutnya, ada 2 macam Megoakgoakan yang dilakukan di Desa Panji. Pertama, permainan Megoak-goakan yang diadakan saat ngembak geni dan Megoak-goakan yang diadakan di Pura Penjenengan yang disebut Megoak-goakan sakral. Megoakgoakan yang diadakan saat Ngembak geni bertujuan untuk menghormati tradisi leluhur di saat menang melawan Blambangan. Tradisi itu diadakan di saat Ngembak geni karena untuk menyambut kepulangan Raja Panji membawa kemenangan. Peristiwa ini bertepatan dengan Hari Ngembak geni. Sedangkan Megoak-goakan sakral, yaitu Megoak-goakan yang harus mengenakan atribut dan sarana kerajaan, dan Megoak-goakan tersebut harus dimainkan oleh orang-orang pilihan yang memiliki garis keturunan dari pasukan 40 yang ikut serta dalam perang melawan Blambangan dengan Ki Barak Panji Sakti. Megoak-goakan sakral ini diadakan di Pura Penjenengan yang biasanya diadakan saat pengerupukan, yaitu sebelum mati geni.
Pura Penjenengan adalah Pura yang dipercaya sebagai tempat Ki Barak Panji Sakti mengalami peristiwa moksa. Megoak-goakan sakral harus diawali dengan upacara yang dilengkapi dengan sarana upacara yang lengkap tanpa kurang satupun. Sedangkan Megoak-goakan yang diadakan oleh masyarakat Desa Panji adalah Megoak-goakan yang dilakukan sebagai bentuk perayaan dan penyambutan atas kepulangan Raja Panji Sakti dan pasukannya yang membawa kemenangan melawan Blambangan, dan permainan bisa dimainkan oleh siapa saja.

Tradisi Megoak-goakan ini menjadi tolak ukur masyarakat Desa Panji untuk penghormatan terhadap Raja Panji dengan pasukannya, yang bernama Teruna Goak. Tradisi Magoak-goakan dapat dikaitkan dengan ajaran Agama Hindu. Dalam Agama Hindu dikenal adanya konsep Tri Hita Karana dimana hubungan yang harmonis sangat diharapkan. Filosofi Tri Hita Karana mengajarkan bahwa kebahagiaan manusia akan dapat dicapai bila manusia mampu menjaga keharmonisan hubungan antar manusia dengan penciptanya (prahyangan), manusia dengan alam (palemahan), dan manusia dengan sesamanya (pawongan) (Windia, 2006: 26)

Permainan Megoak-goakan dimainkan oleh satu regu terdiri dari 11 peserta yang melawan kelompok yang lainnya dengan jumlah yang sama. Supaya tertib, maka dalam arena permainan diatur oleh pecalang. Disebutkan filosofi permainan ini, sebagai wujud purusa pradana (laki-laki melawan perempuan), dalam satu kelompok goak terdiri dari 11 orang, sementara penentuan kemenangan adalah kelompok goak-goakan yang pertama kali mampu menangkap ekor (orang paling belakang) dalam kelompok lawannya, maka dialah pemenangnya. Kehadiran permainan tradisional Megoakgoakan berfungsi mengenalkan dan mengakrabkan peristiwa-peristiwa yang pernah dialami dan dilakukan para leluhur pada 
masa lampau. Hal ini pada hakikatnya juga memberikan hikmah dalam menumbuhkan rasa hormat serta rasa memiliki di hati para penerusnya. Hal ini dapat menumbuhkan karakter bangsa pada anak-anak sehingga anak-anak menghormati jasa-jasa para leluhur dan pahlawannya.

Permainan tradisional Megoak-goakan berfungsi mengembangkankecerdasan. Hal itu terlihat pada peran-peran yang dimainkan pemainnya dengan upaya menangkap lawan ataupun melindungi diri dari serangan lawan. Misalnya, dalam permainan Megoak-goakan pemain yang berperan sebagai gagak (goak) dituntut memiliki kecerdasan atau kesempurnaan akal budi dalam melepaskan diri dari sergapan pemain di belakangnya, cerdas dalam melihat setiap kelengahan/kelalaian dan mencari kesempatan yang baik dan tepat untuk dapat menangkap pemain yang berperan sebagai anak ayam yang di ujung barisan. Selain itu, pemain anak ayam juga harus cerdas menghindari serangan pemain gagak (goak) sehingga tidak mudah tertangkap.

Fungsi Megoak-goakan yang lainnya adalah mengembangkan kreativitas yang terlihat dalam upaya-upaya yang dilakukan pemain dengan memancing musuh agar mudah tertangkap. Dengan kreativitas seorang pemain menyebabkan kesulitan dalam membaca dan menerka arah gerakannya. Pemain yang kreatif, baik dalam peran gagak ataupun peran anak ayam, akan mempunyai gerakan yang bersifat mengelabuhi atau mengecoh lawan. Pemain dalam peran gagak ataupun yang menyelamatkan (pemain anak ayam) selalu dituntut kreativitasnya untuk mengeluarkan gerakan-gerakan spontanitas yang dapat mengelabuhi lawan. Selain itu, sarana permainan tradisional dan variasi bentuk permainan dapat menstimulasi ruang kreativitas anak. Hal ini disebabkan permainan tradisional, termasuk permainan Megoak-goakan lebih menekankan pada proses atau bukan permainan yang sudah jadi sebagaimana permainan modern. Anak-anak mau tidak mau harus mengumpulkan temannya terlebih dahulu, saling berkenalan, menentukan bentuk permainan, memilih penokohan dan peran, memilih lokasi, memilih sarana, serta memilih lagu pengiring. Semua merangsang kreativitas anak sehingga permainan tradisional yang dihasilkan bernilai estetik dan enak untuk dimainkan. Inilah kenapa anak-anak berhak menentukan sarana permainan sesuai selera maupun variasi permainan yang disukainya sehingga anak-anak merasa nyaman dalam memainkan permainan. Bukan tidak mungkin kreativitas anak-anak tersebut akan mengembangkan satu permainan menjadi banyak variasi entah dalam hal sarana, formasi permainan, peran dalam permainan, dan lain-lain.

Permainan tradisional Megoak-goakan juga berfungsi membentuk fisik atau organ tubuh anak-anak. Dalam permainan Megoak-goakan anak-anak dituntut untuk terus bergerak, melompat, berlari, menari, berputar, merangkak, menjinjit, jongkok, dan lain-lain dalam suasana gembira karena dilakukan bersama-sama dengan teman-temannya. Gerakan tersebut secara tidak langsung melatih kelenturan tubuh anak-anak sehingga tidak kaku dan anakanak dapat tumbuh dengan sehat.

Permainan tradisional Megoak-goakan memiliki sejumlah fungsi seperti di atas diakibatkan nilai-nilai karakter dan pekerti bangsa yang terkandung dan tersirat dalam permainan tersebut. Selain mengandung nilai-nilai karakter dan pekerti bangsa, seperti nilai kejujuran, kedisiplinan, kebersamaan, keadilan yang tertanam pada semua jenis permainan tradisional anakanak di Bali, nilai yang secara jelas terlihat sangat dominan dalam permainan Megoak-goakan adalah sikap etis panutan yang dilandasi semangat kepemimpinan. Melalui media permainan Megoak-goakan 
ini juga secara tidak langsung Raja Panji memberikan panutan pada anak-anak agar kelak menjadi seorang pemimpin yang bersimpati, akomodatif, dan senantiasa dekat dengan bawahan. Selain itu, nilai etos kerja keras dan kreatif tercermin dalam permainan tradisional Megoak-goakan. Permainan tradisional menuntut pemain harus bekerja keras dalam menyerang dan menaklukkan musuh ataupun menghindari lawan dengan strategi-strategi tertentu. Hal ini terlihat dalam gerakan-gerakan lincah anakanak dalam permainan yang kadangkala membutuhkan aktivitas fisik yang cukup banyak, seperti berlari, menari, jongkok, merangkak, merayap, berputar-putar, berbalik, atau melompat ke sana ke mari. Di dalam gerakan-gerakan tersebut tersirat nilai etos kerja keras dalam menggapai citacita. Cita-cita Raja Panji Sakti untuk menaklukkan Kerajaan Blambangan diraih justru melalui permainan Megoak-goakan. Secara tidak langsung Raja Panji Sakti menanamkan dan mendidik rakyat serta prajuritnya untuk membiasakan bekerja keras dalam meraih cita-cita. Hal ini ditandai pada pemeran gagak yang berada di ujung depan barisan dengan segala strateginya, karena tidak mudah menangkap anak ayam yang berada jauh di ujung barisan belakang. Formasi permainan seperti itu menggambarkan bahwa penaklukan Kerajaan Blambangan bukan sesuatu yang mudah dilakukan seperti membalikkan tangan karena Blambangan adalah kerajaan besar dan memiliki kekuatan perang yang cukup handal. Oleh karena itu, Raja Panji Sakti harus kreatif menciptakan strategi, baik dalam menghadapi kerajaan Blambangan maupun mengambil hati para prajuritnya. Hal ini tercermin dalam aktivitas dari lakon setiap pemain. Mereka harus kreatif menciptakan gerakan-gerakan agar dapat mengecoh lawan. Menang merupakan target dalam permainan. Karena itu, gerakan-gerakan tersebut membutuhkan semangat kerja keras dan kreativitas tinggi untuk menjadi pemenang dalam permainan ini.

Dua aspek yang saling mendukung antara kerja keras dan kemampuan kreatif yang ditemukan dalam permainan tradisional Megoak-goakan dapat memberikan kontribusi dalam pembentukan karakter bangsa anak-anak yang benar-benar tertanam pada aspek kognitif, afektif, dan konatif (perilaku yang sudah sampai tahap hingga individu melakukan sesuatu tindakan terhadap objek) anak-anak sebagai generasi penerus bangsa Indonesia. Dengan demikian, anak-anak akan menjadi terbiasa bekerja keras dan berkemampuan kreatif dalam menghadapi setiap persoalan hidup bangsa di tengah-tengah era persaingan dan keuletan pada diri setiap orang (Suarka, 2011: 38).

Keunikan permainan ini juga dimainkan dengan iringan musik dari gamelan yang bernama Balaganjur Teruna Goak. Yang menarik dari musik iringan ini adalah melodi utama yang dimainkan oleh instrumen reyong (satu-satunya instrumen yang memainkan melodi pada gamelan Balaganjur). Instrumen ini memainkan melodi yang sederhana dan sangat mudah diingat dan diiringi dengan suara cenceng kopyak yang dimainkan secara bersahut sahutan dengan teknik kakilitan dan cecandatan. Pola ritmenya bervariasi dari pukulan basic atau negteg pukulan "telu" (tiga), dan "enam" (enam) di mana masing-masing terdiri dari pukulan polos (sejalan dengan mat/ketukan) dan sangsih (disela-sela mat). Pola ini dimainkan dengan ekspresi yang bersemangat yang menghasilkan suasana yang riuh dan riang yang menambah keseruan dalam permainan Megoak-goakan ini.

Saat ini, teknologi semakin berkembang dan mempengaruhi semua aspek masyarakat termasuk menenggelamkan permainan tradisional dengan berbagai macam game modern yang mudah didapatkan, yang mengalihkan perhatian anak-anak dan 
generasi muda saat ini. Alasan inilah yang menjadi landasan penulis ingin menganalisa musik iringan permainan tradisional Megoak-goakan, yang nantinya akan menjadi salah satu dasar dalam proses penciptaan karya musik Megoak-goakan dalam irama jazz.

Penelitian ini merupakan langkah konkrit untuk memperkenalkan dan mengingatkan serta melestarikan kembali permainan tradisi yang sarat akan pesan moral dan memberikan efek positif bagi pembentukan karakter pada anak dan generasi muda sebagai ideologi penciptaan musik Bali. Dalam penciptaan musik Bali, setidaknya ada tiga ideologi yang melandasi, yaitu pengabdian, aktualisasi diri, dan profesi komersial (Sugiartha, 2015 :146).

\section{METODE}

Metode yang digunakan dalam karya ini diawali dengan tahap eksplorasi. Pada tahap eksplorasi dilakukan aktivitas penjelajahan menggali sumber ide, pengumpulan data dan referensi, pengolahan dan menganalisa data. Hasil dari penjelahan atau analisis data dijadikan dasar untuk membuat rancangan desain. Pendalaman sejarah dilakukan dengan membaca kepustakaan sejarah Ki Barak Panji Sakti, dan melakukan wawancara dengan tokoh desa adat Panji serta pengamatan objek secara langsung di Desa Panji.

Pada tahap perancangan dilakukan dengan mentranskrip musik dari Megoakgoakan yang dimainkan Balaganjur Teruna Goak ke dalam penotasian, yang kemudian diperoleh bentuk dan struktur lagu dari musik Balaganjur Teruna Goak. Notasi ini kemudian dianalisa menggunakan teoriteori yang mendukung penelitian ini dalam menganalisa musik Teruna Goak. Setelah itu, dilakukan pengklasifikasian data yang diperoleh berlandaskan teori-teori yang digunakan, yaitu teori dari Banoe tentang bentuk dasar musik, di antaranya, melodi, irama, tempo, harmoni. Kemudian, teori dari Mosel yang menganalisa dinamika dan ekspresi dari musik Teruna Goak, serta mengunakan teori dari Prier (2015) yang mengklasifikasikan bentuk lagu. Dari hasil penotasian bentuk lagu dari musik Balaganjur Teruna Goak tersebut, penulis masuk ke dalam tahap improvisasi dengan bereksperimen untuk membuat melodi yang berbeda tanpa menghilangkan motif dari musik Balaganjur Teruna Goak tersebut. Melodi tersebut kemudian dipadukan dengan harmoni untuk mewujudkan satu kesatuan musik yang indah. Tahap ini memakan waktu yang cukup lama karena pencipta juga berusaha untuk memadukan musik ini dengan alat musik tradisi, yaitu kendang sunda sebagai instrumen pemegang rhytm section, seperti drum yang juga akan digunakan dalam format quintet ini. Setelah tahap ini terwujud, selanjutnya melangkah ke tahap perwujudan yang nanti dalam karya "Transformasi Musik Balaganjur Teruna Goak ke dalam Musik Jazz" ini akan diawali dengan musik Tapa Bratha sebagai musik pengantar, sekaligus sebagai simbol bahwa Hari Raya Nyepi telah tiba dan waktunya menyucikan diri. Setelah itu, disambut dengan Ngembak geni yang jatuh sehari setelah nyepi/ matigeni dilaksanakan. Pada momen inilah musik "Transformasi Musik Balaganjur Teruna Goak dalam Irama Musik Jazz" ini ditampilkan, karena di Desa Panji hari Ngembak geni digunakan sebagai ajang untuk bersilaturahmi/bersosialisasi untuk berkumpul bersama dengan teman dan kerabat.

\section{HASIL DAN PEMBAHASAN}

Permainan Megoak-goakan di Desa Panji diringi dengan iringan musik Balaganjur yang dimainkan oleh pemudapemuda dari Desa Panji tersebut dan musik yang dimainkan bertemakan Teruna Goak. Istilah Balaganjur berasal dari kata Bala berarti pasukan atau barisan, Ganjur berarti 
berjalan. Penggabungan kedua kata tersebut (Bala dan Ganjur) kemudian mengalami percepatan penyebutan pada bagian awal (Bala menjadi ble) dan kebiasaan orang Bali menggunakan kata e pepet pada suku akhir kata seperti Bala, pura, dan sebagainya. Percepatan penyebutan Balaganjur menjadi bleganjur ini kemudian menjadi lebih popular. Hingga sekarang, masyarakat Bali masih menyebutnya dengan kata bleganjur, bukan Balaganjur. Jadi, Balaganjur yang kemudian menjadi bleganjur memiliki pengertian suatu pasukan atau barisan yang sedang berjalan, yang kini pengertiannya lebih berhubungan dengan barungan gamelan. Gamelan Balaganjur pada awalnya difungsikan sebagai pengiring upacara ngaben atau pawai adat dan agama. Tapi dalam perkembangannya, sekarang peranan gamelan ini makin meluas. Saat ini, gamelan Balaganjur dipakai untuk mengiringi pawai kesenian, ikut dalam iringan pawai olah raga, mengiringi lomba layang-layang dan ada juga yang dilombakan (Antara, Sudirga, and Santosa, 2018: 98). Balaganjur adalah pengiring prosesi yang paling umum dikenal di Bali dan tergolong barungan madya (Dibia, 1999: 112). Arti barungan madya adalah barung-an sedang yang dimainkan 11 sampai 25 orang. Balaganjur biasa digunakan sebagai pengiring prosesi membawa sesajen ke pura, atau melasti (mengambil air suci) atau upacara ngaben yang diiringi oleh barungan yang sangat dinamis dan bersemangat. $B a-$ laganjur ini terdiri dari beberapa instrumen, seperti 6-12 pasang cenceng kopyak, 2 buah kendang cedungan (lanang dan wadon), 1 buah kajar, 1 buah kempli, dan 2 buah gong besar, 1 buah kempur dan 1 buah pemade, dan reyong adalah satu-satunya kelompok instrumen pembawa melodi (Dibia, 1999: 112).

\section{Bentuk Dasar Musik}

Bentuk dasar musik menurut Banoe ada 4, yaitu melodi, irama, tempo dan harmoni. Melodi utama pada musik Teruna Goak ini dimainkan oleh instrumen Reyong yang menjadi satu-satunya alat musik yang memegang melodi pada gamelan Balaganjur. Ritme pada Balaganjur ini dimainkan dengan instrumen ceng-ceng kopyak yang jumlahnya sekitar 6-12 buah, dan 2 buah kendang cedungan (lanang wadon), 1 buah kajar, 1 buah kempli dan 2 buah gong besar, serta 1 buah kempur dan 1buah pemade. Barungan ini ada kalanya dimainkan dengan tawatawa. Sementara itu, ceng-ceng dimainkan secara kakilitan atau cecandatan, dengan pola ritme yang bervariasi dengan pukulan besik atau negteg pukulan telu (tiga), dan enam di mana masing-masing terdiri dari pukulan polos (sejalan dengan mat) dan sangsih (disela-sela mat), dan sanglo (di antaranya). Sebagaimana halnya ceng-ceng, reyong juga dimainkan dengan pola kakilitan. Tabuhtabuh yang dimainkan dalam Balaganjur terdiri dari gilak yang dimainkan dalam tempo cepat atau sedang dan pelan. Selain dari 4 bentuk dasar musik proses analisis ini juga membedah ekspresi dan dinamika yang terdapat dalam musik Balaganjur Teruna Goak.

"Ketika menyanyikan atau memainkan suatu karya musik, sebaiknya diperhatikan juga kekuatan nada. Mungkin pada bagian tertentu perlu dimainkan secara kuat, sedangkan pada bagian lain dimainkan secara lembut atau lebih lemah. Keras lembutnya cara dalam memainkan musik tersebut disebut dinamika"(Permadi, 2014: 14).

Menurut Banoe, dengan adanya dinamika itu pemain mendapatkan gambaran bagaimana memainkan atau menyanyikan suatu karya musik, sehingga sesuai dengan keinginan komponis. Contoh-contoh tanda dinamika antara lain yaitu: forte dimainkan dengan keras; piano dimainkan secara lembut; mezzoforte dimainkan agak keras; dan mezzopiano dimainkan agak lembut.

Dalam kaitan dengan itu, ekspresi di dalam musik adalah sebuah petunjuk di dalam lagu yang digunakan untuk mengarahkan seorang pemain agar mampu me- 
mainkan sesuai dengan yang diinginkan komponis. Selanjutnya, ekspresi dalam musik menurut Jamalus (1998: 38) adalah ungkapan pemikiran dan perasaan yang tertulis dalam sebuah komposisi musik dan mencakup semua suasana dari tempo, dinamika, dan warna nada dari unsur-unsur musik. Tanda ekspresi meliputi cantabile (seperti bernyanyi), dolce (manis), appassionato (bernafsu) (Prier, 2015).

\section{Bentuk Musik}

Adapun betuk lagu menurut Prier terdiri atas:

1. Bentuk lagu tiga bagian, yakni “Bentuk lagu dengan tiga kalimat periode yang berlainan" (Prier, 2015: 12).

2. Bentuk lagu dua bagian.

"Bentuk lagu dua bagian adalah bentuk lagu yang terdiri dari dua kalimat yang berlainan" (Prier, 2015: 8). Kontras dari 2 kalimat tersebut harus ditelaah secara hati-hati karena ia menentukan pola pembawaan. Kontras ini dapat terwujud sebagai kontras dinamika, kontras irama, kontras tonalitas, kontras harmoni, kontras arah lagu, dan ulangan pun dapat dimasukkan ke dalam kontras.

3. Bentuk lagu satu bagian.

"Bentuk lagu satu adalah suatu kesatuan yang dapat berdikari, mempunyai arti dalam dirinya sediri karena bentuknya bulat" (Prier, 2015: 7).

\section{Simetris}

"Bentuk simetri berarti bahwa suatu lagu atau komposisi musik yang jika satu kalimat misalnya terdiri dari delapan ruang birama dibagi dalam dua bagian yang sama panjangnya yang membentuk kalimat yang berbeda. Empat birama pertama disebut pertanyaan atau kalimat depan dan empat birama berikutnya disebut jawaban atau kalimat belakang" (Prier, 2015: 3).

Menurut Prier dalam Permadi (2014), “Bentuk musik (form) adalah suatu gagasan atau ide yang nampak dalam pengolahan atau susunan semua unsur musik dalam sebuah komposisi (melodi, irama, harmoni dan dinamika. Ide ini mempersatukan nadanada musik serta terutama bagian-bagian komposisi yang dibunyikan satu persatu sebagai kerangka" (2014: 14-15).

Berdasarkan penjelasan di atas pencipta menjadikan teori ini sebagai landasan penciptaan dari karya ini.

\section{Struktur Musik}

Struktur musik terdiri dari beberapa komponen atau beberapa unsur-unsur yang sangat penting dalam pembentukannya sehingga menjadi satu kesatuan musik yang sempurna, antara lain yaitu:

1. Priode atau Kalimat Periode adalah sejumlah ruang birama (biasanya 8 atau 16 birama yang merupakan suatu kesatuan).

2. Frase. "Frase adalah suatu unit dalam musik yang secara umum tersusun dalam empat birama yang diakhiri dengan kadens atau pengulangan. Dalam suatu komposisi musik frase dibedakan menjadi dua, yaitu frase/kalimat tanya atau anteseden dan frase/kalimat jawab atau konsekuen" (Stein, 1979: 22).

3. Motif. "Motif adalah unsur lagu yang terdiri dari sejumlah nada yang dipersatukan dengan suatu gagasan atau ide" (Prier, 2015: 3).

\section{Fungsi Musik}

Fungsi musik di Bali di antaranya sebagai sarana ritual dan hiburan. Selain itu, juga sebagai salah satu media pendidikan. Hal ini dapat dilihat dalam semua permainan tradisional yang hampir semuanya dimainkan dengan nyanyian atau lagu dolanan yang memiliki pesan-pesan positif yang dapat membentuk karakter anak bangsa, yang di Bali disebut dengan sekar rare. Sedangkan menurut Meriam dalam Permadi fungsi musik adalah:

"Sebagai sarana hiburan atau entertainment, sebagai alat komunikasi, sebagai 


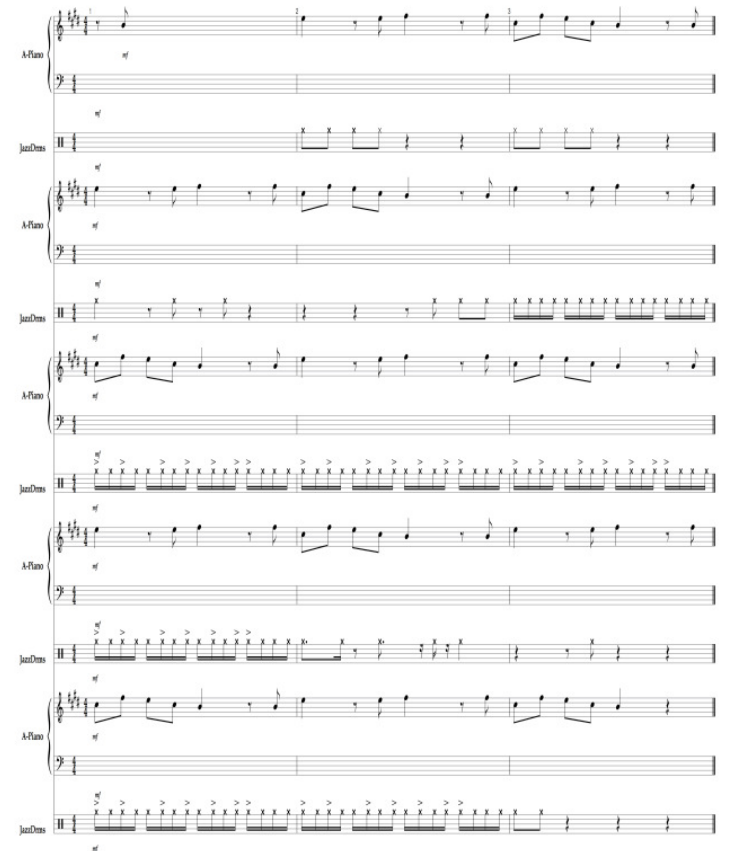

Gambar 1. Notasi Balaganjur Teruna Goak (Sumber: Ade Surya Firdaus, 2018)

suatu persembahan, sebagai respon fisik, sebagai suatu keserasian norma-norma di dalam masyarakat, sebagai institusi sosial dan bagaian dari ritual keagamaan, sebagai sarana dalam kelangsungan stabilitas suatu kebudayaan, sebagai wujud integritas dan identitas atau suatu ciri khas dalam masyarakat, sebagai media pengungkapan emosional, sebagai penghayatan estetis" (Permadi, 2014: 18).

Selain itu, di Bali ada yang disebut dengan musik instrumen dan musik vokal, seperti seni Karawitan atau musik tradisi yang ada di Bali. Musik ini meliputi bentuk-bentuk seni suara vokal (tembang) dan seni musik instrumental (gamelan) yang bernada slendro dan bernada pelog yang merupakan ciri musik tradisi di Bali.

\section{Struktur Melodi pada Balaganjur Teruna Goak}

Menurut Nettl, ada 2 pendekatan dalam mendeskripsikan musik, yakni dengan cara menganalisa dan mendeskripsikan apa yang kita dengar dan menulis dan mendeskripsikan apa yang kita lihat dengan mentranskripnya dengan notasi. Berlandaskan 2 pendekatan ini, penulis melakukan penotasian ke dalam bentuk

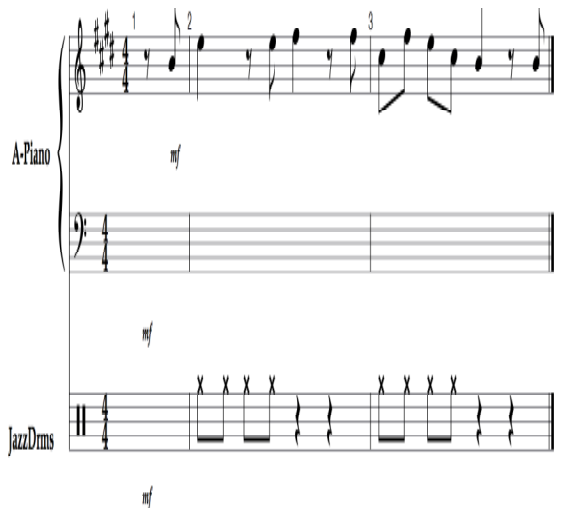

Gambar 2. Kalimat Tanya pada musik Teruna Goak (Sumber: Firdaus, 2018)

simbol visual seperti terlihat pada gambar 1. Hal inilah yang disebut transkripsi dan analisis (1964: 131).

Dilihat dari 4 unsur dasar musik, yaitu melodi, irama tempo dan harmoni, hasil yang didapatkan dari penotasian tersebut adalah:

1. Melodi utama yang dimainkan dengan instrumen reyong terdiri dari 2 bagian. Melodi yang pertama dimulai dari ketukan ke-4 up, dan berakhir diketukan ke-3. Begitu juga pada melodi yang kedua tetapi dengan ritmis yang berbeda, dengan tangga nada pelog yang berjumlah 5 nada.

2. Irama yang dimainkan adalah irama 4/4 (4 not quarter dalam setiap bar)

3. Tempo yang dimainkan adalah allegro (cepat dengan kisaran 120-139 bpm/ beat per minute)

4. Harmoni yang dihasilkan apabila ditelaah ke dalam alat musik piano menghasilkan harmoni pergerakan chord dari chord 1 - 2 -1 (E major, F\# minor, E major) dengan nada dasar $\mathrm{E}$.

5. Dinamika musik Teruna Goak ini dimainkan dengan nyaring yang dilambangkan dengan lambang $m f$ (mezzo forte) hingga $f$ (forte) yang artinya keras.

6. Ekspresi yang penulis tangkap dalam musik Balaganjur ini adalah ekspresi bersemangat sesuai dengan karakter Balaganjur.

7. Bentuk lagu yang ditangkap dari 
penotasian ini ada 2 bagian yang dimulai dengan ketukan yang sama tetapi dengan ritmis yang berbeda, yang menandakan bagian pertama sebagai frase antiseden/kalimat tanya dan bagian ke-2 sebagai frase konsekuen/jawaban.

Frase pertama yaitu dari bar ke-4 up sampai bar ke-2 ketukan ke-3, frase ke-2 dari bar ke-2 ketukan ke-4 up sampai bar ke-3 ketukan ke-3.

Dari penotasian pada ceng-ceng, anggota Balaganjur yang memainkan ceng-ceng banyak memainkan not $1 / 16$ (semiquaver) secara singkupasi dengan aksen pengulangan.

\section{Tahap Eksplorasi}

Pada tahap ini pencipta mengolah data yang diperoleh dari tahap penjajakan sejarah sehingga menemukan nilai-nilai yang tersirat dalam tradisi Megoak-goakan tersebut, seperti sportifitas, kejujuran dan keberanian. Setelah mengamati secara langsung tradisi Megoak-goakan ini, pencipta juga melihat keunikan yang ada pada musik Balaganjur Teruna Goak sebagai pengiring permainan Megoak-goakan seperti yang dijelaskan di atas. Hal ini yang

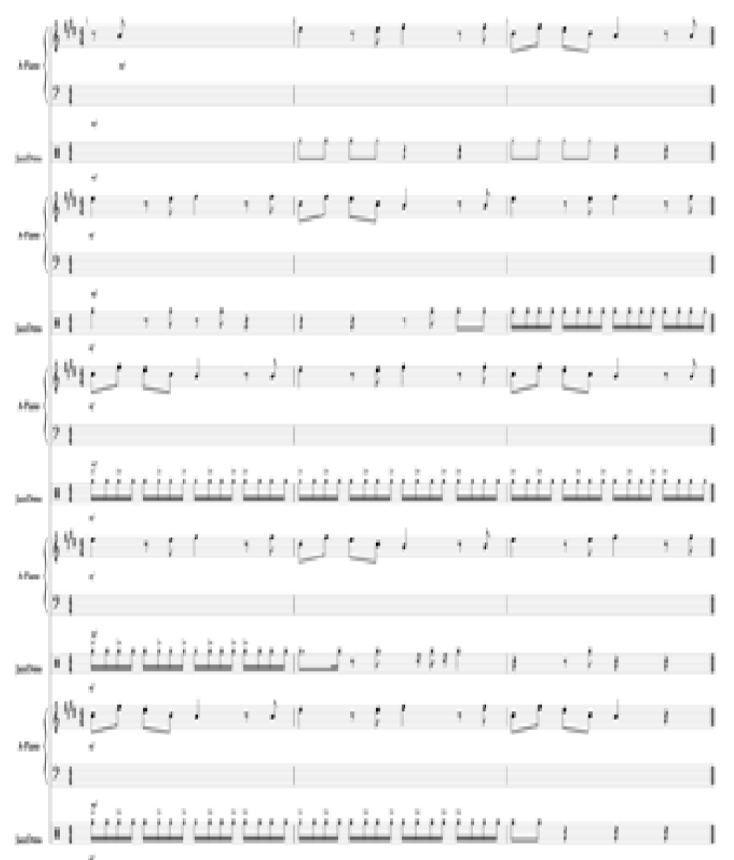

Gambar 3. Notasi Balaganjur Teruna Goak (Sumber: Firdaus, 2018) akhirnya menggiring ide kreatif pencipta untuk mentransformasikannya ke dalam musik jazz. Hasil dari penotasian musik Balaganjur Teruna Goak ini dikembangkan lagi menjadi suatu musik yang berbeda tanpa menghilangkan identitas dari musik Balaganjur Teruna Goak dengan tahapan yang akan dibahas selanjutnya.

\section{Tahap Improvisasi}

1. Tahap Eksperimen

Dalam tahap improvisasi pencipta bereksperimen menggabungkan musik Megoak-goakan ini ke dalam format quintet yang dimainkan dengan alat musik modern (piano, doublebass, drum, saxophone) dan alat musik tradisi sunda yaitu (kendang sunda) dengan tetap mempertahankan idiom musik barat yaitu jazz. Ditahap ini pencipta bereksperimen mengembangkan melodi utama dari musik Balaganjur Teruna Goak yang telah divisualkan dengan notasi musik ini menjadi aransemen musik yang dapat dimainkan oleh format quartet. Seperti yang dapat dilihat pada gambar 3 dan gambar 4 .

Gambar 3 adalah notasi musik Balaganjur Teruna Goak secara utuh, dan pada gambar 4 adalah notasi musik yang sudah

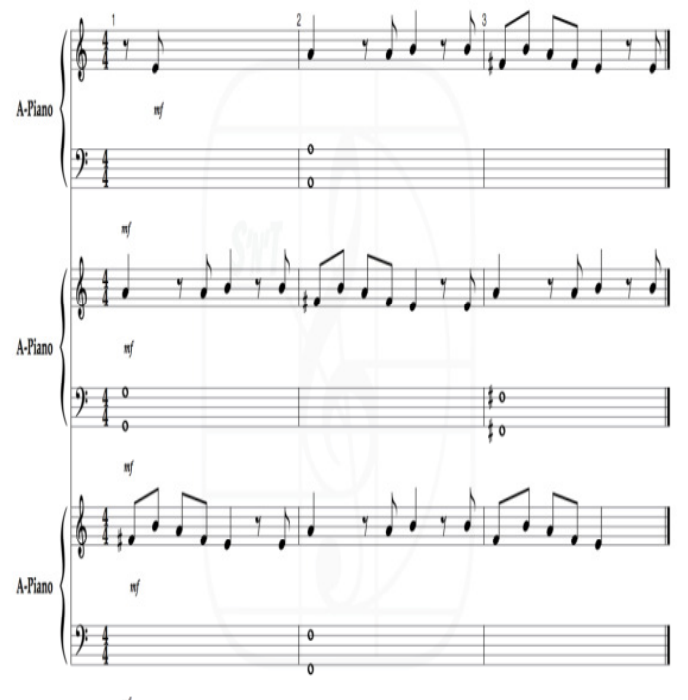

Gambar 4. Notasi Balaganjur Teruna Goak dengan Chord (Sumber: Firdaus, 2018) 


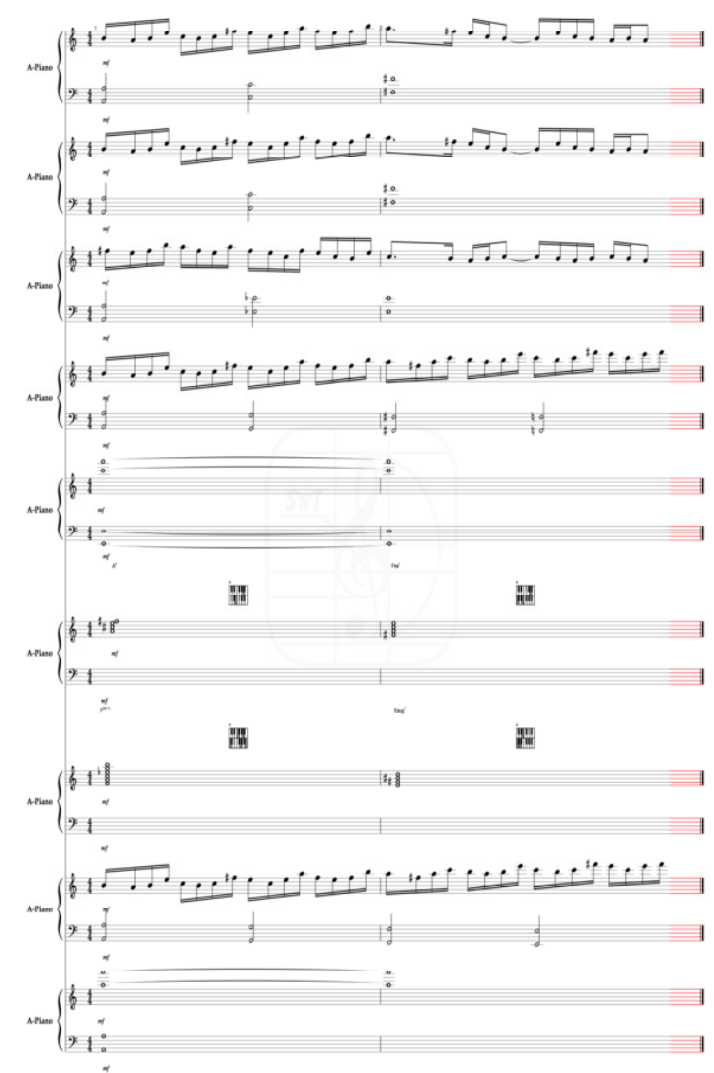

Gambar 5. Notasi Transformasi

Musik Balaganjur Teruna Goak ke dalam Musik Jazz Bagian A, B, A. (Sumber: Firdaus, 2018)

dikembangkan dengan penambahan chord atau harmoni pada bagian Bass Clef, dan bagian ini akan menjadi bagian pertama atau intro pada karya ini nantinya. Selanjutnya, pengembangan dilakukan lagi untuk memperoleh bentuk lagu A-B-A seperti yang dapat dilihat pada notasi gambar 5 .

Pada notasi gambar 5 dapat dilihat melodi pertama dan kedua sama persis, dan melodi ketiga dan keempat yang berbeda dengan melodi pertama dan kedua. Di sini, pencipta melakukan pengembangan dari musik Balaganjur Teruna Goak tanpa menghilangkan motif tanya jawab yang terdapat pada musik Balaganjur Teruna Goak. Kedua pengembangan ini dilakukan tanpa menghilangkan identitas dari musik Balaganjur Teruna Goak itu sendiri. Pada bagian improvisasi pada notasi lagu ini ditandai dengan simbol chord sebagai penanda bahwa bagian tersebut adalah bagian untuk berimprovisa-

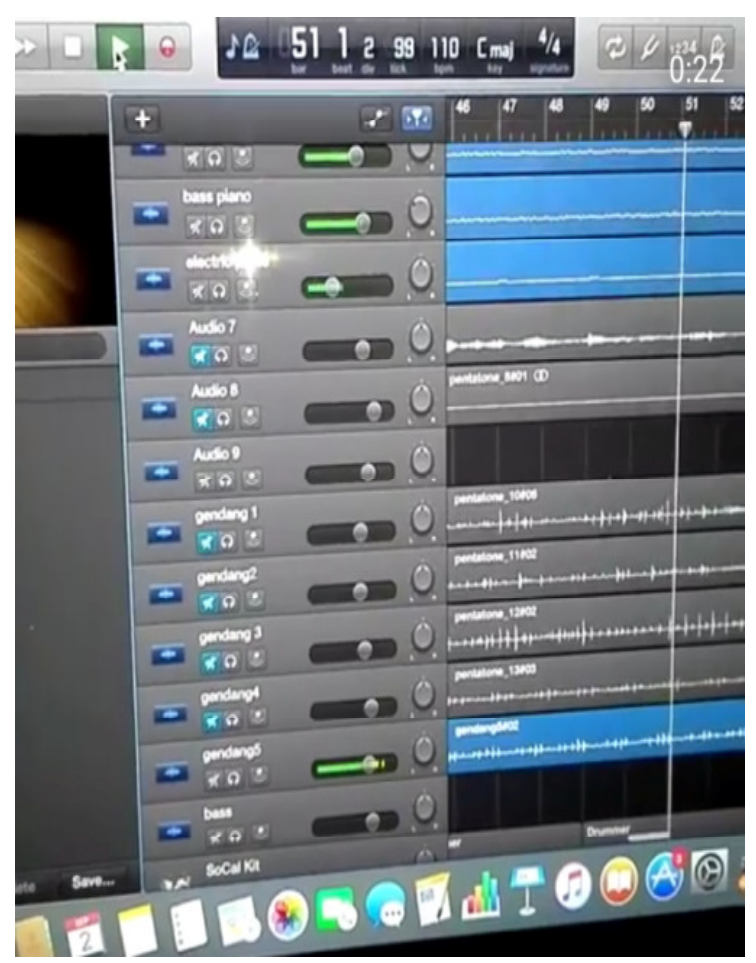

Gambar 6. Proses recording dengan aplikasi Garage Band

(Sumber: Firdaus, 2018)

si atau merepresentasikan lagu ini dengan intepretasi masing-masing musisi.

\section{Tahap Recording Awal}

Tahap ini dilakukan mengunakan aplikasi Garage Band. Pada tahap ini, recording hanya dilakukan untuk mengevaluasi musik yang sudah divisualkan tersebut agar dengan mudah dapat diperdengarkan dan dievaluasi kembali oleh pencipta dan musisi pendukung lainnya untuk memperoleh hasil yang maksimal.

\section{Tahap Latihan \& Kolaborasi}

Pada tahap ini, pencipta memaparkan semua gagasan ide penciptaannya kepada musisi pendukung lainnya. Proses latihan dilakukan berulang-ulang yang cukup menyita waktu untuk memperoleh harmonisasi yang maksimal dan indah, sehingga musik yang dihasilkan nantinya dapat mewakili apa yang ingin pencipta sampaikan kepada para pendengarnya.

\section{Tahap Perwujudan}

Dalam tahap perwujudan karya "Transformasi Musik Balaganjur Teruna Goak Ke- 


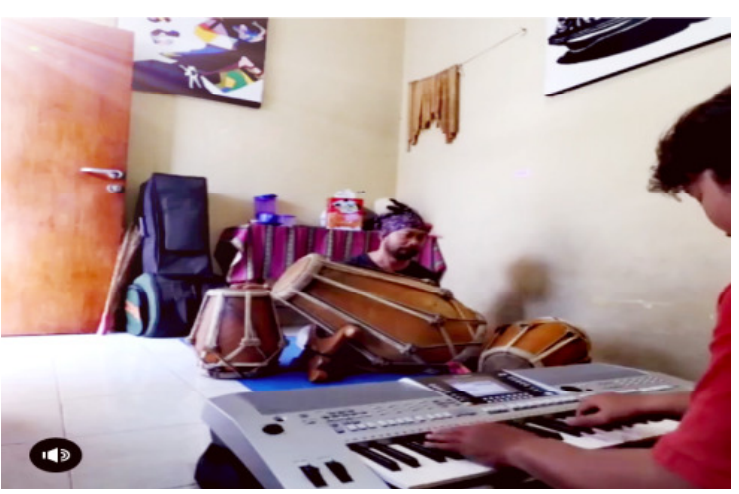

Gambar 7. Proses Kolaborasi dengan Kendang Sunda (Sumber: Firdaus, 2018)

dalam Musik Jazz" nantinya akan diawali dengan musik Tapa Bratha yang akan ditampilkan sebagai simbol bahwa Hari Raya Nyepi telah tiba. Itu adalah waktu untuk menyucikan diri dan alam semesta dengan membuang segala hal negatif yang telah lampau untuk menyongsong tahun baru Saka. Musik Tapa Bratha ini ditampilkan dengan durasi 2 menit untuk menggiring emosional penonton dan menempatkan mereka kedalam suasana sakral saat menyambut Hari Raya Nyepi. Setelah itu, disambut dengan Ngembak geni yang jatuh sehari setelah nyepi/matigeni dilaksanakan. Pada momen inilah karya "Transformasi Musik Balaganjur Teruna Goak ke dalam Musik Jazz" ini ditampilkan.

\section{SIMPULAN}

Transformasi Megoak-goakan Desa Panji dalam irama Jazz adalah karya musik yang tercipta akibat fenomena termarginalkannya permainan tradisional, salah satunya adalah permainan Megoak-goakan. Fenomena tersebutlah yang menstimulasi sisi kreativitas pencipta untuk berkontribusi melestarikan permainan tradisional melalui karya musik yang berbentuk musik hybrid, yaitu percampuran musik barat dan musik tradisi Bali dan Sunda ini. Karya ini mentransformasikan tradisi Megoakgoakan tersebut ke dalam karya musik jazz yang dikemas ke dalam 3 bagian, yaitu In-

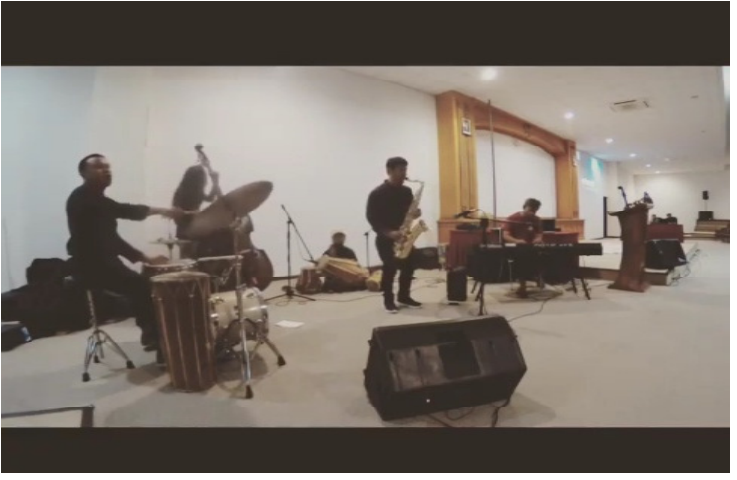

Gambar 8. Pementasan Karya (Sumber: Firdaus, 2018)

terpretasi I Gusti Anglurah Panji Sakti, Tapa Brata dan karya utama, yaitu Transformasi Megoak-goakan Desa Panji dalam irama Jazz yang akan dimainkan secara medley.

Proses penciptaan dimulai dari tahap penjajakan sejarah yang menyiratkan nilainilai sportifitas, kejujuran, dan keberanian. Pesan dan makna dari permainan tradisional Megoak-goakan ini yang sangat baik dalam membentuk karakter bangsa, yaitu dari nasionalisme, kejujuran dan keberanian seorang Raja Panji Sakti yang menjadikannya salah satu Raja yang disegani dan memiliki kekuasan yang luas di era pemerintahannya. Ini yang menjadi pijakan pencipta ingin melestarikan permainan tradisional agar tidak terlupakan. Selain itu, juga pencipta ingin melestarikan budaya dan nilai-nilai kearifan lokal yang terdapat dalam permainan tradisional.

Tahap improvisasi pencipta bereksperimen menggabungkan musik Megoakgoakan ini ke dalam format quintet yang dimainkan dengan alat musik modern (piano, doublebass, drum, saxophone) dan alat musik tradisi Sunda, yaitu kendang sunda dengan tetap mempertahankan idiom musik barat, yaitu jazz. Selanjutnya, dilakukan perekaman dengan mengunakan aplikasi Garage Band. Tahap perwujudan karya "Transformasi Musik Balaganjur Teruna Goak ke dalam Musik Jazz" dengan banyak menampilkan improvisasi yang terpola antara pemain musik. 


\section{Daftar Pustaka}

Antara, IMAB., IK Sudirga, and H. Santosa. (2018). “Cak Ganjur: Sebuah Komposisi Musik Vokal Gabungan Cak dan Balaganjur." Kalangwan 4 (9), 96-104.

Dibia, W. (1999). Selayang Pandang Seni Pertunjukan Bali. Yogyakarta: Masyarakat Seni Pertunjukan Indonesia.

Hawkins, A. (1990). Mencipta Lewat Tari. Sumandiyo Hadi (ed.). Surakarta: Solo Press.

Jamalus. (1998). Pengajaran Musik Melalui Pengalaman Musik. Jakarta: Depdikbud proyek pengembangan lembaga pendidikan dan tenaga kependidikan.

Nettl, B. (1964). Theory and Method in Ethnomusicology. London: Collie Star, Publisher.

Permadi, W. (2014). Moral dalam Sekar Rare di Bali. Universitas Negeri Yogyakarta.

Prier, K.E. 2015. Ilmu Bentuk Musik. 5th ed. Yogakarta: Pusat Musik Liturgi.

Santosa, H. \& D. Kustiyanti. (2018). “Mrědangga: Sebuah Penelusuran Awal tentang Gamelan Perang Di Bali." Kalangwan 4 (1), 16-25.

- (2017). "Seni Pertunjukan Bali pada Masa Dinasti Warmadewa." Mudra Jurnal Seni Budaya 32, 81-91.
(2018). "Gamelan Banjuran, Perubahan dan Kelanjutannya." In Seminar Nasional Agama, Adat, Seni dan Sejarah di Zaman Milenial. Denpasar: UNHI Press.

Sastrodiwiryo, S. (2011). I Gusti Anglurah Panji Sakti Raja Buleleng 1599-1680. Edisi Kedua. Denpasar: Pustaka Bali Post.

Sentanu, A.A.N. (2004). I Gusti Anglurah Panji Sakti. Retrieved Desember 23, 2018, from http://www.buleleng. com/index.html

Stein, L. (1979). Structure and Style, The Study and Analysis of Musical Forms. New Jersey: Summy Brichard Music.

Suarka, I.N. (2011). Nilai Karakter Bangsa dalam Permainan Tradisional Anka-Anak Bali. Jiwa Atmaja (ed.). Denpasar, Bali: Udayana University Press.

Sugiartha, I.G.A. (2015a). "Bentuk dan Konsep Estetik Musik Tradisonal Bali." Panggung, 25 (1), 46-60.

-----------. (2015b). “Pergulatan Ideologi dalam Penciptaan Musik Kontemporer Bali." Panggung, 25 (2), 121-36.

Windia, N. (2006). Konsep Tri Hita Karana dalam Tradisi Bali. Surabaya: Paramita. 